\title{
Exploring Cosmopolitanism
}

One of the consequences of globalisation has been an increase in the global movement of people. More people are moving to another country than at any previous time in history, comprising what Castles and Miller call the 'Age of Migration'. Not only are the numbers of immigrants increasing, albeit suffering a slight reversion of the trend in the years following the global financial crisis, but the diversity of immigrant intakes has also increased. Some contemporary immigrants are millionaire business migrants or health and financial professionals who fly first or business class to reach their destination city, for most migration reinforces urbanisation. Other immigrants come with skills and qualifications that are in short supply in their host country. Some come to settle and take up citizenship while others in one chapter of what is a global journal of circular migration where skills and qualifications-indemand are a global passport to mobility. Others are temporary immigrants with short stay visas designed to allow migrant labour to fill labour shortages that might soon disappear as globalisation restructures the economy of nations, throwing up new industries while devouring or relocating others. Some are unwanted, undocumented immigrants who risk their lives, and hat of their families, to escape conflict, persecution, poverty, tyranny, flood or famine to seek a new life as a refugee or part of the shadow-life of the underground economy.

Of course the international movement of people has predated nation states, and is as old as history itself. As a consequence, the peoples of most nations are characterised by cultural, religious, ethnic and linguistic diversity to varying degrees. In many cases, minority immigrant populations suffer from discrimination and racism, stereotyping and distancing from the majority population, themselves often the products of immigration flows decades or centuries ago. Immigration and immigrant populations are, almost universally, controversial and politicised, with right-wing anti-immigration political parties gaining momentum. In western counties like Britain and Germany, multiculturalism has recently been proclaimed as a failure by Prime Minister Cameron and Chancellor Merkel. In Australia, a nation that has embraced multiculturalism since the 1970s, issues of the 'boat people' and citizenship have dominated the political landscape in the last decade. 
Issues of immigrant identity and belonging, particularly related to Muslim immigrant communities, have occupied a central place in political and academic debate in recent decades. As a consequence there has been a re-interrogation of the concept of cosmopolitanism and its appropriateness as a theoretical framework to progress a theoretical understanding of, and a political resolution of, the politics of diversity in contemporary societies. In the last decade the literature on cosmopolitanism has flourished, with a lively debate emerging on the concept and theory of cosmopolitanism and its appropriateness for understanding and dealing with issues of diversity in western and non-western contemporary societies.

As Baruti argues in 'Cosmopolitanism with a twist', the lead article in this special issue on Cosmopolitanism, 'cosmopolitanism has made a spectacular comeback to save the day'. But cosmopolitanism has also generated a great deal of noise from the arguments as to whether the glass of cosmopolitanism is half full or half empty which, Baruti argues, is causing such a stir that it is defeating its harmonious purpose. Her paper reviews the definition of and theory of cosmopolitanism from its historical origins (from the early Greeks to Kant) to its contemporary theorists, canvassing concepts of mutual affinity, ethnogamy and cosmopoliteness. Baruti calls for a time-out in the debate, proposing what she calls a cosmopolitan-approach to cosmopolitanism.

The cultural turn in the humanities and social sciences is the point of departure for Stephanie Lawson and her article 'Cosmopolitan Pluralism: Beyond the Cultural Turn'. With its critique of universalist ideas developed in European political and social thought, the cultural turn has focussed on the pluralism and difference within political communities and between them and on the instability if not the impossibility of foundations for knowledge. Lawson argues that the cultural turn's deep-seated opposition to virtually all forms of universalism leads to a strong critique of and often rejection of cosmopolitanism. This outcome, she suggests, is a consequence of the fact that the conceptions of culture embodies in this critique are derived mainly from the discipline of anthropology. This tendency has meant the concept of culture embodies in the humanist tradition has been either ignored or rejected. Lawson makes the case for a reconsideration of what the humanist tradition can contribute to the conceptualization of culture and its deployment in political thought and action. Such rethinking can lead to the development of a conception of cosmopolitan pluralism that 
continues to value difference and particularity while remaining committed to a conception of humanity.

In Australia, multiculturalism has been the philosophical and policy framework for dealing with cultural diversity for nearly four decades if we date its arrival with the Whitlam Labor Government's Immigration minister, Al Grassby. From the heyday of multiculturalism under the Fraser, Hawke and Keating governments, the policy content of, and institutional framework for, multiculturalism was substantially dismantled under the conservative Howard government. The successive Labor governments of Rudd and Gillard have partially resurrected multiculturalism, though without the apparent enthusiasm of the Hawke and Keating Labor governments. In the Ministry announced by Gillard following her marginally successful federal election in 2010, no minister or parliamentary secretary had formal responsibility for multiculturalism, an event unthinkable in the last quarter of the $20^{\text {th }}$ Century. This oversight was later rectified when Kate Lundy was renamed Parliamentary Secretary for Immigration and Multicultural Affairs and a new commitment to multiculturalism in the form of the Australian Multiculturalism Council was established in August 2011.

One of the problems with Australian multiculturalism is that it has been established on the foundation of essentialist notions of ethnicity, ethnic community and Australian identity. In their article 'Scaling Up Connections: Everyday Cosmopolitanism, Complexity Theory \& Social Capital', Jenny Onyx and her colleagues take as their point of departure the weakness of the homogenisation of ethnicity in Australia and the need to explore a more cosmopolitan vision of a society comprising of changing and multiple social networks. Using the concept of everyday cosmopolitanism embedded within the theory of social capital and complexity theory they emphasise the importance on conducting research into 'the grassroots, ordinary interactions that occur between people in their daily lives, focusing on social sites such as neighbourhoods, schools, workplaces and the like'. This provides us with an understanding of 'a lived cosmopolitanism, which sees individuals of different cultures routinely negotiating across difference in order to coexist within a shared social space', something not possible within the existing framework of Australian multiculturalism.

In his article 'Playing the triangle: Cosmopolitanism, Cultural Capital and Social Capital as intersecting scholarly discourses about social inclusion and marginalisation in Australian 
public policy debates', Andrew Jakubowicz explores a similar terrain. He compares the usefulness of the concepts of cosmopolitanism, cultural capital and social capital for understanding recent multiculturalism debates, the social ecology of young Muslim Australians and Chinese politics in Australia.

Critics of immigration and multiculturalism often point to the anti-social behaviour of immigrant youth and their lack of connectedness to and identification with the host society. In their article 'Identities, Aspirations and Belonging of Cosmopolitan Youth in Australia' Jock Collins, Carol Reid and Charlotte Fabiansson draw on a survey of 340 young men and women most of whom were first or second generation immigrants living in West and South western Sydney to explore issues related to aspirations, social networks, belonging and identity. They conclude that these immigrant youth are not disaffected, isolated, fearful and angry but that they are, in the main, hopeful and optimistic. They hold strongly to values of family, friendship, loyalty and trust, but claim cosmopolitan, hybrid identities that reflect the cultural diversity of their family’s history.

One critique of cosmopolitanism it that it is elitist and western, resonating only with the lives of 'business class cosmopolites' and having nothing to do with ordinary people in western societies let alone any relevance for the rest of the peoples of the globe. Yet this critique ignores the long-standing cosmopolitan history of countries in Asia, Latin America and Africa and the cosmopolitan history of working class trade union and labour movements. In her article 'Tracing Southern Cosmopolitanisms: the intersecting networks of Islam, trade unions, gender \& communism, 1945-1965’ Heather Goodall takes as a point of departure the historical cosmopolitanism of Indonesian and Indian society and of working class peoples. She recounts the relationships among working class Australians, Indonesians and Indians in the aftermath of an intense political struggle of the maritime trade unions in Australia from 1945 to 1949 in support of Indonesian independence. Drawing in particular on the history of Rabindranath Tagore, Tan Malaka, Phyllis Johnson and Sylvia Mullins, Goodall argues that they had been brought together by intersections between the networks established through colonialism, like trade unions, communism and feminism, with those having much longer histories, like Islam. Their political networks have a vision in 1945 of future universal and transnational networks across the Indian Ocean that today might be called cosmopolitanism. 
One feature of the recent literature on cosmopolitanism is the diversity of disciplinary backgrounds and research tradition is on which it draws. In her article 'I-Witnessing; Reflections on cosmopolitanism in Kigali’ Hilary Yerbury uses auto-ethnography - IWitnessing - to recount her experiences with a Rwandan woman and her family in Kigali, Rwanda, as a lens for understanding cosmopolitanism. Drawing on cosmopolitan theory and using concepts such as the guest, the stranger, the cosmopolite and cosmopolitan curiosity, Yerbury recounts her discussions with her informant, Louise, and reflects on her experiences with Louise's household during her stay at a time replete with family emotion and turmoil.

Stefano Mercanti’s article 'Displacing Androcracy: Cosmopolitan Partnerships in Bapsi Sidhwa's Water' reflects on cosmopolitanism through his critical analysis of the novel Water, based on the film of the same name and published in 2006. Water was set in the 30s at the time of Gandhi's Freedom Movement against the British Raj. Both the written text and film versions were very controversial. There were riots when first attempts were made to shoot the film in the holy city of Varanasi while effigies of the film director, Deepa Mehta, an independent film maker born in India and living in Canada since 1973, were burnt as one militant protester attempted suicide by jumping into the Ganges, resulting in a change of location for the film. Mercanti explores these reactions to the film and it makers and their powerful social critique of the book and the film, particularly social mores regarding the status of women. Mercanti argues that Water has been making waves in projecting multiple cosmopolitan trajectories in the ways the filming and the writing of its story have been crossing over local and national boundaries, religious and political alliances.

This study contributes to the current cosmopolitan debate by highlighting equal recognition and inclusion as a viable moral engagement towards diversity, through which dominator binary rankings are transcended by valuing mutually empathic relationships. Set against the backdrop of Gandhi's Freedom Movement, Water pushes the boundaries of India's maledominant cultural narratives beyond patriarchal predicaments by questioning the religious tradition and the oppressive constraints imposed on Hindu widows. By applying Riane Eisler's 'partnership model' to the analysis of the novel, with a brief reference to Deepa Mehta's homonymous film, Mercanti explores how Sidhwa's characters move toward more caring and life-enhancing scenarios by portraying relationships of mutual support, thus overcoming the rigid discourses imposed by dominator hierarchies. 
Tracey Dowdeswell explores the roots of contemporary cosmopolitan theory in the writings of Immanuel Kant in her article 'Cosmopolitanism, Custom, and Complexity: Kant's Cosmopolitan Norms in Action '. Her particular concern is to link the contemporary critique of the Western and Eurocentric nature of Cosmopolitanism and hence its incompatibility with cultural pluralism to the universal norms such as hospitality, reciprocity, and publicity (transparency and free political participation) that were identified by Kant. Her paper attempts to address these criticisms of Cosmopolitanism by studying examples of Cosmopolitan norms in action. Her aim is to demonstrate that Cosmopolitan norms can be found in a diverse array of human communities and cultures and that they are not only compatible with pluralism, but are instrumental in its success and vitality. Dowdeswell claims that the flourishing of the civil societies she draws on as examples to support her argument shows that the adoption of Cosmopolitan norms are strongly correlated with successful outcomes and well-being.

Jon Marshall, in his article 'Cosmopolitan Sophistry: Grounding Politics in Disorder and Uncertainty' goes back to the roots of cosmopolitanism in Plato and before Plato to explore insights which he claims can be useful to social theorists and cosmopolitans generally. His analysis looks at some of the creative paradoxes and tensions which arise within cosmopolitanism's use, its rhetorical function and its sophistic beginning. For Marshall cosmopolitanism claims to be both a term of analysis and a political objective and deals with multiplicity, apparent contradictions and unity. His argument is that it is how terms like cosmopolitanism are used politically or sociologically that is part of the sociological or political dimension of life. They are not separate domains, and the term works through its evocation of opposites and the dynamics of disorder.

Jock Collins

October 2011 